\title{
Методологічні основи та складові програми відновлення активності та участі дітей з геміплегічною та диплегічною формами церебрального паралічу засобами ерготерапії та фізичної терапії
}

\author{
УДК 796:616.831-009.11-053.4-085 \\ О. Кущенко
}

Національний університет фізичного виховання і спорту України, Київ, Україна

\begin{abstract}
Резюме. Мета. Визначити методичні основи побудови і складові програми відновлення активності й участі дітей з геміплегічною і диплегічною формами церебрального паралічу засобами ерготерапії і фізичної терапії. Методи. Аналіз науково-методичної літератури, синтез і узагальнення. Результати. Визначено, що побудова програми повинна враховувати мульти-, інтер- і трансдисциплінарний підходи, філософсько-методологічний підхід міжнародної класифікації функціонування, методику SMART у встановленні цілей, сімейно-центровий підхід, нейропластичність головного мозку і інші аспекти. Сформовано блок-схему процесу реабілітації з комплексним використанням засобів. Висновки. Сучасні методологічні підходи в організації процесу фізичної терапії і ерготерапії разом із раціональним поєднанням засобів $\epsilon$ основою для підвищення участі й активності дітей з церебральним паралічем.
\end{abstract}

Ключові слова: ерготерапія, відновлення, функціонування, активність, участь, фізичні навантаження, фізична реабілітація.

Методологические основы и составляющие программы восстановления активности и участия детей с гемиплегической и диплегической формами церебрального паралича средствами эрготерапии и физической терапии

А. Кущенко

Резюме. Цель. Определить методические основы построения и составляющие программы восстановления активности и участия детей с гемиплегической и диплегической формами церебрального паралича средствами эрготерапии и физической терапии. Методы. Анализ научно-методической литературы, синтез и обобщение. Результаты. Определено, что построение программы должно учитывать мульти-, интер- и трансдисциплинарный подходы, философско-методологический подход международной классификации функционирования, методику SMART в постановке целей, семейно-центровой подход, нейропластичность головного мозга и другие аспекты. Сформирована блок-схема процесса реабилитации с комплексным использованием средств. Выводы. Современные методологические подходы в организации процесса физической терапии и эрготерапии наряду с рациональным сочетанием средств являются основой для повышения участия и активности детей с церебральным параличом.

Ключевые слова: эрготерапия, восстановление, функционирование, активность, участие, физические нагрузки, физические упражнения, физическая реабилитация.

Methodological bases and constituents of the program for the recovery of activity and participation of children with hemiplegic and diplegic forms of cerebral palsy by means of ergotherapy and physical therapy

\section{O. Kushchenko}

Abstract. Objective. To determine methodological bases of the design and the components of the program for restoring the activity and participation of children with hemiplegic and diplegic forms of cerebral palsy using the means of ergotherapy and physical therapy. Methods. Analysis of scientific and methodological literature, synthesis and generalization. Results. It was determined that the construction of the program should take into account multi-, inter- and transdisciplinary approaches, the philosophical and methodological approach of the international classification of functioning, the SMART method in setting goals, the family-center approach, brain neuroplasticity and other aspects. 
A block diagram of the rehabilitation process with complex usage of means was formed. Conclusions. Modern methodological approaches to the organization of the process of physical therapy and ergotherapy along with a rational combination of means are the basis for increasing the participation and activity of children with cerebral palsy.

Keywords: ergotherapy, recovery, functioning, activity, participation, physical loads, physical exercises, physical rehabilitation.

Постановка проблеми. Аналіз останніх досліджень і публікацій. Реабілітація дитячого контингенту $\epsilon$ соціально значущою проблемою фрізичної терапії та ерготерапії [3, 4]. У цьому аспекті одним із найактуальніших питань дитячої неврології $\epsilon$ дитячий церебральний параліч (ДЦП), який залишається основною причиною інвалідності дітей [16].

Комплексність i всебічний характер програм реабілітації найбільш поширені у роботі з дітьми, хворими на ДЦП. Реабілітаційні програми містять різноманітні засоби фрізичної терапії, ерготерапії, мовної терапії та доповнюються медичними і хірургічними процедурами, розважальними заходами, адаптацією до школи і навчання, психосоціальною підтримкою, застосуванням ортезів і іншого адаптивного обладнання [18, 19]. Актуальність комплексних і міждисциплінарних підходів до етапної реабілітації дітей із церебральним паралічем обумовлена як епідеміологічними фракторами, так і гуманістичними тенденціями розвитку суспільства [12].

Хоча у багатьох наукових дослідженнях розкриваються окремі аспекти досліджуваної проблеми, цілісного бачення системи організації побутової практики дітей з церебральним паралічем на заняттях з ерготерапії, трудотерапії не представлено [5]. Проблеми значущості діяльності фрізичного терапевта, ерготерапевта, вихователя дитини 3 ДЦП та сім'ї потребують подальшого дослідження.

Мета дослідження - визначити методичні основи побудови та складові програми відновлення активності та участі дітей з геміплегічною та диплегічною формами церебрального паралічу засобами ерготерапії та фрізичної терапії.

Методи дослідження: аналіз науково-методичної літератури, синтез та узагальнення.

Результати дослідження та їх обговорення. Метою розробленої програми реабілітації $\epsilon$ підвищення рівня соціально-побутової активності та участі дітей з геміплегічною та диплегічною формами ДЦП.

Розробка курсу реабілітації для покращення соціально-побутової активності базувалася на поєднанні найефективніших методик. Також методичні аспекти розробки програми реабілітації, організація процесу реабілітації, а також проектування і корекція індивідуального плану для дітей з ДЦП мають враховувати:
- необхідність дотримання мульти-, інтер- та трансдисциплінарного підходів;

- фрілософрсько-методологічний підхід Міжнародної класифрікації функціонування для визначення вектору впливу засобів фрізичної терапії та ерготерапії;

- правила методики SMART у постановці індивідуальних цілей (завдань) для дітей та батьків;

- сімейно-центровий підхід, дитино-центровий підхід, особливості потреб пацієнтів і членів їх родини;

- принципи фрізичної реабілітації, педагогічні принципи;

- нейропластичність головного мозку;

- клінічні особливості перебігу захворювання дитини.

Зокрема, характерною особливістю реабілітації дітей з ДЦП $є$ врахування клінічної фрорми і тяжкості захворювання, а також пов'язаних із ним порушень, фізіологічного віку дитини й соціально-економічних чинників. Також бралося до уваги те, що візуальні, слухові та когнітивні розлади, судоми, нездатність до навчання й емоційні проблеми можуть вплинути на результати реабілітаційних втручань $[13,23]$.

Відповідно до сучасних тенденцій реабілітація дитячого контингенту вимагає мультидисциплінарного командного підходу до інвалідності або недоліків, що обумовлені фізичними, розумовими, сенсорно-перцептивними або когнітивними розладами у зв'язку 3 пренатальними, натальними або постнатальними причинами [18].

Мультидисциплінарна (багатодисциплінарна) реабілітація на сьогодні $\epsilon$ ключовим підходом у парадигмах медико-санітарної допомоги та відновлення хворих. Такий підхід має принципове значення у відновленні рухових функцій, активності та участі дітей з ДЦП. Реабілітація при ДЦП - складний процес, спрямований на забезпечення дітям i їx сім'ям найкращої можливої якості життя. Вона розглядає індивіда 3 позиції фрізичних, розумових, емоційних, комунікативних та реляційних аспектів (холістична фрункція) і передбачає також їх сімейний, соціальний і екологічний контекст (екологічна функція). Реабілітація складається 3 цілого ряду комплексних заходів не тільки у галузі охорони здоров'я, але й у сфрері освіти і догляду [17]. 
Цей холістичний (цілісний) і екологічний підхід підтримується Міжнародною класифікацією функціонування (МКФ) Всесвітньої організації охорони здоров'я, яка $\epsilon$ єдиною основою мультидисциплінарного підходу.

Проте загальний чи глобальний погляд на допомогу дітям з ДЦП, окрім залучення багатьох учасників, передбачає перехід від багатопрофільної перспективи до інтегрованого мульти-, інтер- та трансдисциплінарного підходу [25].

Мультидисциплінарність у реабілітації ДЦП спирається на знання і практику різних дисциплін та фахівців (невролога, фрізіотерапевта, офттальмолога, педіатра, психолога, логопеда, педагога), які працюють у сфері своєї компетенції, а інтердисциплінарність інтегрує, вбирає і скоординовано і послідовно гармонізує зв'язки між різними дисциплінами для підтримання належного розвитку дітей з ДЦП [24].

Трансдисциплінарний підхід $€$ необхідною перспективою інтеграції природних, соціальних і наук про здоров'я у контексті гуманітарних наук, що дозволяє кожній з них вийти за свої традиційні межі [14]. Трансдисциплінарність дає змогу фрахівцям із різних дисциплін співпрацювати і розробляти загальну структуру втручання (наприклад, процесу реабілітації) для досягнення спільної мети. Трансдисциплінарність поєднує в собі мульти- і інтердисциплінарність з активним підходом, здатна генерувати нові знання, а також встановлює холістичний підхід до реабілітації при ДЦП, в якій всі зацікавлені сторони відкладають власні конкретні перспективи, щоб охопити одну глобальну мету для оптимального довгострокового догляду дітей з ДЦП [25].

Методологічний підхід МКФ $є$ важливим i сучасним аспектом формування програм реабілітації пацієнтів [10]. Відзначимо, що Всесвітня організація охорони здоров'я пропонує МКФ як один із найбільш актуальних інструментів для форомуання державної політики в галузі реабілітації, а також для статистичного аналізу здоров'я в плані економічного впливу, показників захворюваності та інвалідності серед населення, при медико-соціальній експертизі. Визначення МКФ представлено як багатоцільова класифікація зі стандартною мовою і рамками для проведення опису стану здоров'я і пов'язаних із ним станів [2].

Дорослий варіант МКФ, а також версія для дітей і підлітків $є$ біопсихологічними моделями, які все частіше визнаються як ефективний інструмент для опису стану здоров'я та інвалідності, i основою для планування і моніторингу реабілітаційних заходів [25].
Сутність терміну «фрункціонування» у МКФ розглядається як інтегративний показник здоров'я людини на рівнях організму (структура і фрункції), адаптивної поведінки (активність) і участі в соціальних ситуаціях, беручи до уваги вплив контексту (фракторів зовнішнього середовища й особистісних) [6].

Основні сорери активності та участі, за МКФ, включають мобільність (пересування у просторі, використання допоміжних засобів), самообслуговування і самоорганізацію, навчання і комунікації (мовлення, розуміння, розпізнавання, спілкування, міжособистісна взаємодія), суспільне й особисте життя [2]. Тож для найбільш есрективного впливу і повного розуміння пацієнта як складної системи, а також реабілітації як процесу впливу засобами фрізичної терапії та ерготерапії, враховували взаємозв'язок складових концепції МКФ.

Так, стосовно структури та фрункції при ДЦП насамперед враховують наявність мозкових ушкоджень, що призводять до спастичності та інших порушень моторної функції, відхилень у психічних функціях. Це у свою чергу впливає на зниження функціональної активності та участі, оскільки обмежується незалежність і збільшується роль сторонньої допомоги, що супроводжується можливими проявами депресії, порушеннями поведінки.

На практиці використання підходу МКФ, за даними літератури [2], дозволяє: виконати всебічний аналіз обмежень життєдіяльності; змінити напрямок впливу заходів реабілітації та уточнити послідовність їх застосування; проаналізувати фрактори контексту; оцінити результативність реабілітації.

Стосовно методичних особливостей планування та керування реабілітаційним процесом у роботах зазначають, що досягнення мети програми реабілітації залежить від особливостей формулювання цілей, або завдань $[1,20]$. Тож 3 цієї причини використовувалася методика SMART-цілей для встановлення індивідуальних цілей пацієнтів та їх оточення.

Загалом мета визначається як предмет прагнення, те, що треба чи бажано здійснити, ідеальне передбачення результату певної діяльності. Мета відповідає на питання «Чого потрібно досягти?», а завдання - «Якими діями цього можна досягти?» [1].

Ця досить дієва та популярна методика SMART застосовувалася 3 метою покращення результатів програми реабілітації, підвищення якості управління процесом реабілітації та взаємодії [10].

В основі цих можливостей лежить той фракт, що при передачі інформації між людьми зміст iï часто перекручується, оскільки однакові 
повідомлення сприймаються по-різному. Основа нерозуміння виявляється у неможливості людей дати однакову оцінку одній і тій самій ситуації [7]. У роботі з дітьми, що мають ДЦП, необхідність максимального порозуміння $\epsilon$ дуже актуальною, оскільки досить часто наявні різні порушення фізичного й психічного розвитку, поведінки. Також ця методика $\epsilon$ актуальною у роботі з батьками, які на фоні постійного стресу також не завжди правильно сприймають інформацію.

Поліпшити рівень порозуміння покликана методика SMART, що базується на застосуванні критеріїв. Таким чином, у роботі з дітьми, хворими на ДЦП, правильна постановка завдань і цілей означає, що вони:

- $\epsilon$ конкретними та зрозумілими для всіх учасників реабілітаційного процесу. Цілі мають бути визначені у формі конкретних результатів;

- можуть бути об'єктивно виміряні: мета повинна вказувати на можливість і необхідність вимірювання / оцінки результату у конкретних показниках;

- $\epsilon$ досяжними, здійсненними, реалістичними для конкретного пацієнта у конкретних умовах;

- забезпечені ресурсами для досягнення і не протипоставляються між собою;

- мають співвідноситися 3 конкретним часовим терміном досягнення.

Фахівці відновного лікування припускають можливим визначення цілей у фрорматі SMART 3 акцентом у постановці цілей не тільки на фрахівця і пацієнта, а й на близьке оточення (сім'ю, родичів і кураторів). Пацієнти, які беруть участь у встановленні цілей і визначають певні практичні критерії, показують більшу прихильність до самої практики (фрізичної терапії чи ерготерапії) [20]. Це $€$ дуже актуальним для зацікавлення i включення до процесу дітей з ДЦП.

Центральну роль сім'ї (сімейно-центрований підхід) у довгостроковій перспективі догляду за дітьми з ДЦП та їх реабілітації (фрізична терапія і ерготерапія) підтверджують численні дослідження, які розглядають сім'ю як частину мульти-інтер-трансдисциплінарного підходу. Літературні джерела вказують на сильний вплив сімейноцентрованого підходу у сприянні соціально-психологічному благополуччю дітей і їх батьків, що обумовлює підвищення задоволеності послугами. На сьогодні сімейно-центрований підхід вважається найкращим підходом у фрізичній терапії та ерготерапії серед дітей з ДЦП [15, 22, 25].

Асоціація догляду за здоров'ям дітей розробила підхід, який:

- фокусується на щоденних потребах дітей з ДЦП;
- розглядає батьків як основні ресурси для життя своїх дітей;

- підтримує ідеї про те, що сім'ї і фрахівці повинні співпрацювати в рамках програми реабілітації дитини, що фрахівці повинні підтримувати батьків у виконанні своїх обов'язків;

- говорить про те, що ефективність заходів щодо сервісу та зручності повинна грунтуватися на цінності, перевагах, пріоритетах і потребах сімей [21].

Відповідно до сімейно-центрованого підходу, основною метою довгострокового догляду $\epsilon$ поліпшення стану дитини і якості життя сім'ї, підвищення задоволеності батьків від їх участі у програмі реабілітації, оскільки вони краще знають потреби і здатності дитини. Поставивши сім'ю в центрі цього підходу, ми визнаємо її центральну роль у розвитку дитини і в успішному результаті реабілітації, розуміння потреб своєї дитини [25]. Таким чином, сім'я $\epsilon$ невід'ємним елементом забезпечення мульти-інтер-трансдисциплінарного догляду та співпрацює з іншими зацікавленими сторонами в медичних рішеннях. Такий підхід допомагає полегшити стан батьків і поліпшити їх сприйняття догляду, який отримує їхня дитина.

Крім того, при проведенні програми враховувався дитино-центровий підхід, що $є$ відображенням ролі дітей з ДЦП (стадії розвитку). Цей підхід дозволяє не випускати з поля зору головного одержувача допомоги й розширити просторові й часові рамки надання допомоги, орієнтованої на реальні потреби таких дітей [25].

Отже, діти з ДцП і члени їх сімей посідають центральне місце у програмі реабілітації, що спрямована на досягнення дітьми кращих можливостей в плані підвищення рівня їх активності й участі, а також підвищення якості їх життя. Визнання i прийняття до уваги потреб дітей 3 ДЦП, враховуючи складність патологічного стану, етап реабілітації і рівень розвитку дитини, а також досяжність поставленої мети, відбувалося з оглядом на те, що мета може і повинна змінюватися залежно від віку, життєвих умов і навколишнього середовища. Дитино-центровий підхід дозволяв встановити індивідуальні й індивідуально-цільові завдання, що доповнювалися та поєднувалися з методикою SMART.

Фізіологічною основою програми реабілітації була нейропластичність, яка відбувається за рахунок френомену нейронного дарвінізму, феномену динамічної реорганізації (рекрутингу), феномену реорганізації афрерентних i ефрерентних шляхів, френомену постнатального нейроангіогенезу, 


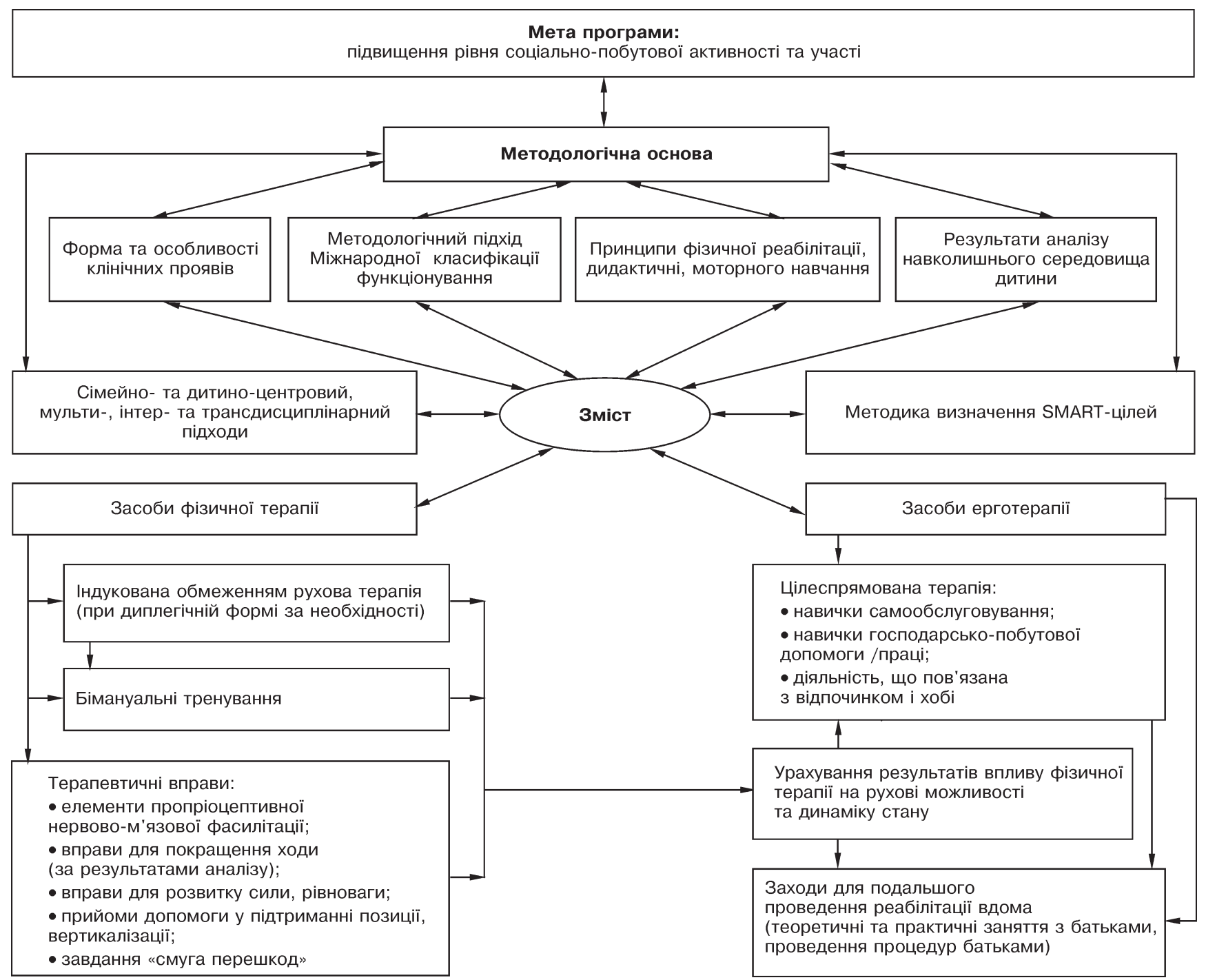

Рисунок 1 - Методологічна основа та зміст програми реабілітації дітей з дитячим церебральним паралічем

а також проявляється у вигляді «розширення карт», «сенсорного перерозподілу», «компенсаторної заміни», «захоплення дзеркальної ділянки кори» [8].

Програма (рис. 1) побудована з урахуванням проведеного аналізу літературних джерел [8, 9, 11], а індивідуальний підхід і наповнення курсу базувалися на отриманих даних оцінки конкретної дитини.

Включення методик фрізичної терапії та ерготерапії у розроблені програми втручань для дітей з ДЦП відбувалося 3 дотриманням наявності науково-обгрунтованої теоретичної та практичної бази. Програма була побудована з урахуванням сучасних концепцій.

Виходячи з явища нейропластичності, використовували такі принципи проведення заходів реабілітації серед дітей з ДЦП для покращення соціально-побутової активності:
- постійне використання наявної активності (нейронні зв'язки та схеми, які не беруть активної участі у виконанні завдань, деградують);

- постійне використання і покращення наявної активності (тренування може посилити конкретну функцію);

- повторення завдань (індукція пластичності вимагає достатнього повторення);

- тривалість процедур / тренувань (різні форми пластичності виникають упродовж різного часу під час тренування);

- наявність динаміки в інтенсивності (індукція пластичності вимагає достатньої інтенсивності тренувань);

- усвідомлення завдань (наявність мотивації, уваги та винагороди, що фрормує значущість для кодування);

- перенесення рухових можливостей на активність та участь (за МКФ). 
3 метою приросту сили застосовували елементи силових тренувань нижніх і верхніх кінцівок. Для підвищення моторної активності, покращення активності та участі у заняття з фахівцями включали елементи індукованої обмеженням рухової терапії (СІMT), цілеспрямовану терапію (goal-directed training), бімануальні тренування, заняття фрізичними вправами для балансу та ходи, заходи для подальшого проведення реабілітації вдома (теоретичні та практичні заняття 3 батьками, проведення процедур батьками).

Під час застосування методик ерготерапії та фрізичної терапії враховували принципи моторного навчання [8]:

- особиста ініціатива активності;

- визначений ступінь когнітивної активності;

- урахування індивідуальних особливостей;

- відповідній рівень складності діяльності;

- достатня кількість повторень конкретної навички, виду діяльності;

- варіабельність тренування (зміна умов, темпу, швидкості);

- наростаюча складність рухової активності на межі можливостей;

- увага на відсутні компоненти дії;

- самостійне виявлення та виправлення помилок у діях;

- значущість діяльності і перенесення ії у щоденну активність.

Вибір рівня складності (або спрощення завдань) здійснювався на основі аналізу результатів діагностичного дослідження за такими критеріями:

- велика моторика - вміння сідати, вставати, ходити, підніматися і спускатися сходами тощо;

- дрібна моторика - маніпуляції з предметами (штовхати, тягнути, перевертати, тримати і за необхідності випускати з рук тощо);

- зорово-моторна координація;

- мислення та імітація (можливість впізнавати предмети, виконувати нескладні вказівки, доручення, слухати, відповідати на запитання зрозумілим способом, а також повторювати дії).

Ерготерапевтична оцінка як основа для визначення індивідуальної спрямованості покращення активності та участі мала визначені ключові моменти. Перший - це необхідність достатньої гнучкості для прийняття до уваги індивідуальних потреб дитини та іï сім'ї (сімейно-центровий підхід) без жорстких норм, оскільки діяльність пацієнта визначається в індивідуальному порядку. Зазначимо, що серед пацієнтів з когнітивними порушеннями роль відповідей членів сім'ї на запитання та допомога у виявленні проблем з точки зору дитини та її потреб стає ще важливішою.
Комплексна і повна оцінка ерготерапевта та фрормування напрямку втручань здійснювалися у сорерах самообслуговування, продуктивної діяльності та дозвілля, враховували ролі та рольові очікування дитини та її сім'ї, а також проблеми, які визначалися дитиною або членами сім'ї самостійно. Окрім того фокусування робилося на навколишньому середовищі дитини, що підтверджувало важливість проблем.

Встановлення рівня задоволеності пацієнта наявним рівнем виконання діяльності та рольових очікувань також справляло позитивний вплив на залучення пацієнта до процесу ерготерапії з самого початку та підвищувало рівень включення у терапевтичний процес. Оцінка важливості необхідна для визначення аспектів, які потребують першочергового втручання.

З'ясування у бесіді з дитиною та її сім'єю про їхні типові повсякденні заняття тих дій, які необхідно чи бажано виконувати, але виконання яких неможливе або має незадовільний рівень, дозволяє ерготерапевту визначити і мати справу з життєвими реаліями, розширювати використання цільових задач і активностей. Таким чином підтримується правило, що пацієнти несуть відповідальність за своє здоров'я і власний терапевтичний процес.

Висновки. Методологічною основою розроблення і реалізації програми відновлення соціально-побутової активності засобами фрізичної терапії та ерготерапії для дітей з геміплегічною та диплегічною формами ДЦП були методологічний підхід Міжнародної класифрікації фрункціонування; форма та особливості клінічних проявів; сімейно- та дитино-центровий, мульти-, інтер- та трансдисциплінарний підходи; результати аналізу навколишнього середовища дитини; принципи фрізичної реабілітації та дидактичні; моторного навчання; методика визначення індивідуальних SMART-цілей.

Діти проходили курс за індивідуальними програмами, що включали засоби ерготерапії та фрізичної терапії. Застосовувалися такі заняття фрізичною терапією: індукована обмеженням рухова терапія (при диплегічній формі за необхідності), бімануальні тренування та комплексна лікувальна гімнастика. Ерготерапевтичні втручання включали цілеспрямовану терапію та заходи для подальшого проведення реабілітації вдома (теоретичні та практичні заняття з батьками, проведення процедур батьками, корекція середовища проживання дитини). Цілеспрямована терапія зосереджувалася на фрормуванні навичок самообслуговування, господарсько-побутової допомоги / праці, активності, що пов'язана з відпочинком і хобі.

Перспективи подальших досліджень полягають в оцінці ефрективності розробленої програми. 


\section{Література}

1. Аникеев Д. М. Цель и задачи физического воспитания студентов в программно-нормативных документах Украины / Д. М. Аникеев // Физ. воспитание студентов. - 2010. - Т. 5. - С. 3-6.

2. Буйлова Т. В. Международная классификация функционирования как ключ к пониманию философии реабилитации / Т. В. Буйлова // МедиАль. - 2013. - № 2 (7). - С. 26-31.

3. Вітомський В. Методичні основи побудови програми із фізичної реабілітації для дітей шкільного віку з функціонально єдиним шлуночком серця / В. Вітомський // Молодіж. наук. вісн. Східноєвроп. нац. ун-ту ім. Л. Українки (серія «Фізичне виховання і спорт»). - 2015. - Вип. 18. - С. 111116.

4. Вітомський В. Фізична реабілітація дітей з вродженими вадами серця: огляд зарубіжного досвіду та досягнень / В. Вітомський // Теорія і методика фіз. виховання і спорту. - 2015. - № 3. - С. 48-54.

5. Доценко О. О. Організація соціальної практики дітей дошкільного віку з дитячим церебральним паралічем на заняттях з трудотерапії / О. О. Доценко, Д. С. Бараненкова // Наук. часопис НПУ ім. М. П. Драгоманова (серія 19 «Корекційна педагогіка та спеціальна психологія»). 2014. - № 25. - C. 41-50.

6. Казьмин А. М. Прикладное значение Международной классификации функционирования, ограничений жизнедеятельности и здоровья детей и подростков (краткий обзор литературы) [Электронный ресурс] / А. М. Казьмин, Г. А. Перминова, А. И. Чугунова // Клиническая и специальная психология. - 2014. - Т. 3, № 2. - Режим доступа : http: / /psyjournals.ru /psyclin /2014 /n2 /Kazmin_et_al. shtml.

7. Кузнецова T. Целеполагание по правилам [Электронный ресурс] / Т. Кузнецова // Новый менеджмент. - 2007. - № 1. - Режим доступа : http: //www.new-management.info /issues /2007/1/8.

8. Основи соціальної педіатрії : навч.-метод. посіб. : у 2 т.; за ред. В. Ю. Мартинюка. - К. :ФОП Верес О.І., 2016. - Т. 1. - 480 с.

9. Основи соціальної педіатрії : навч.-метод. посіб. : у 2 т.; за ред. В. Ю. Мартинюка. - К. :ФОП Верес О.І., 2016. - Т. 2. - 480 с.

10. Раад Абдул Хаді Мохаммад Алалван, Вітомський В., Вітомська М. Програма фізичної реабілітації пацієнтів після хірургічного лікування розривів ахіллового сухожилка // Х Міжнар. конф. «Молодь та олімпійський рух» 24-25 травня 2017 року. - С. 415-416.

11. Финни Н. Р. Ребенок с церебральным параличом. Помощь, уход, развитие / Н. Р. Финни. - М. : Теревинф, 2005. - 336 с

12. Шевиов А. Г. Сучасні міждисциплінарні підходи до етапної комплексної реабілітації дітей із церебральним паралічем / А. Г. Шевцов, Г. М. Хворова // Наук. часопис нац. пед. ун-ту ім. М. П. Драгоманова (серія 19 «Корекційна педагогіка та спеціальна психологія»). - 2013. - № 23. C. $281-285$.

13. Bovend'Eerdt T. J. Writing SMART rehabilitation goals and achieving goal attainment scaling: a practical guide / T. J. Bovend'Eerdt, R. E. Botell, D. T. Wade // Clin. Rehab. - 2009. - Vol. 23. - P. 352-361.

14. Choi B. C. Multidisciplinarity, interdisciplinarity and transdisciplinarity in health research, services, education and policy: 1. Definitions, objectives, and evidence of effectiveness / B. C. Choi, A. W. Pak // Clin. Invest. Med. 2006. - Vol. 29, Iss. 6. - P. 351-364.

15. Dirks $T$. The role of the family in intervention of infants at high risk of cerebral palsy: a systematic analysis / T. Dirks, M. Hadders-Algra // Dev. Med. Child Neurol. - 2011. - Vol. 53 (Suppl 4). - P. 62-67.

16. Fahimzad A. Common infections among disabled children admitted to hospital / A. Fahimzad, D. Babaie, J. Ghoroubi, G. H. Zahed, T. Rafieli // Archives of Pediatric Infectious Diseases. - 2013. - Vol. 1, Iss. 2. - P. 71-74. - Retrieved from doi:10.5812/pedinfect.9075.

17. GIPCI Gruppo Italiano Paralisi Cerebrali Infantili. La valutazione delle funzioni adattive nel bambino con paralisi cerebrale. / E. Fedrizzi (ed.). - Milan: Franco Angeli Editore, 2002. - $225 \mathrm{p}$

18. Gunel K. M. Rehabilitation of children with cerebral palsy from a physiotherapist's perspective / K. M. Gunel // Acta Orthop. Traumatol. Turc. - 2009. - Vol. 43, iss. 2. - P. 173-180. Retrieved from doi:10.3944 / AOTT.2009.173.

\section{References}

1. Anikeyev, D.M. (2010). Cel i zadachi fizicheskogo vospitaniya studentov v programmno-normativnyh dokumentah Ukrainy [Purpose and tasks of physical education of students in programmatic-normative documents of Ukraine]. Fizicheskoye vospitaniye studentov - Physical Education of Students, 5, 3-6 [in Russian].

2. Bujlova, T.V. (2013). Mezhdunarodnaya klassifikaciya funkcionirovaniya kak klyuch k ponimaniyu filosofii reabilitacii [International classification of functioning as a key to understanding the philosophy of rehabilitation]. MediAl, 2 (7), 26-31 [in Russian]

3. Vitomskyi V. (2015). Metodychni osnovy pobudovy prohramy iz fizychnoyi reabilitatsiyi dlya ditey shkil'noho viku z funktsional'no yedynym shlunochkom sertsya [Methodical Bases of Construction of Program of Phisical Rehabilitation for Schoolchildren with Functoinal Single Ventricle of Hear]. Molodizhnyy naukovyy visnyk Skhidnoyevropeys'koho natsional'noho universytetutu imeni Lesi Ukrayinky (ser. «Fizychne vykhovannya i sport») - Youth Scientific Bulletin named after Eastern European National University named after Lesia Ukrainka (ser. «Physical education and sport»), 18, 111-116 [in Ukrainian].

4. Vitomskyi, V. (2015). Fizychna reabilitatsiya ditey z vrodzhenymy vadamy sertsya: ohlyad zarubizhnoho dosvidu ta dosyahnen' [Physical rehabilitation of children with congenital heart disease: a review of foreign experience and achievements]. Teoriya i metodyka fizychnoho vykhovannya i sportu - Theory and Methods of Physical Education and Sports, 3, 48-54 [in Ukrainian].

5. Dotsenko, O.O., \& Baranenkova, D.S. (2014). Orhanizatsiya sotsial'noyi praktyky ditey doshkil'noho viku z dytyachym tserebral'nym paralichem na zanyattyakh $z$ trudoterapiyi [Organization of social practice of preschool age children with infantile cerebral palsy in occupations from occupational therapy]. Naukovyy chasopys natsional'noho pedahohichnoho universytetu imeni M.P. Drahomanova (ser. 19 "Korektsiyna pedahohika ta spetsial'na psykholohiya») - Journal of the National Pedagogical University named after M.P. Drahomanov (ser. 19 «Correctional Pedagogy and Special Psychology»), 25, 41-50 [in Ukrainian].

6. Kaz'min, A.M., Perminova, G.A., \& Chugunova, A.I. (2014). Prikladnoye znacheniye Mezhdunarodnoy klassifikatsii funktsionirovaniya, ogranicheniy zhiznedeyatel'nosti i zdorov'ya detey i podrostkov (kratkiy obzor literatury) [Applied value of the International Classification of Functioning Restrictions of Life and Health of Children and Adolescents (a brief review of the literature)]. Klinicheskaya i spetsial'naya psikhologiya - Clinical and special psychology, Vol. 3, 2. Retrieved from http: / /psyjournals.ru /psyclin /2014 /n2 / Kazmin_et_al. shtml.

7. Kuznecova, T. (2007). Celepolaganie po pravilam [The goal-setting according to the rules]. Novyy menedzhment - New management, 1 . Retrieved from http: / /www.new-management.info /issues /2007 /1 /8 [in Russian]

8. Martinyuk, V.Y. (Ed.). (2016). Osnovy sotsial'noyi pediatriyi [Fundamentals of social pediatrics]. (Vols. 1-2, Vol. 1). Kyiv: FOP Veres 0.I., 480 [in Ukrainian].

9. Martinyuk, V.Y. (Ed.). (2016). Osnovy sotsial'noyi pediatriyi [Fundamentals of social pediatrics]. (Vols. 1-2, Vol. 2). Kyiv: FOP Veres 0.I., 480 [in Ukrainian].

10. Raad Abdul Hadi Mohammad Alalwan, Vitomskiy, V., \& Vitomska, M. (2017). Prohrama fizychnoyi reabilitatsiyi patsiyentiv pislya khirurhichnoho likuvannya rozryviv akhillovoho sukhozhylka [Program of physical rehabilitation of patients after surgical treatment of Achilles tendon ruptures]. Proceedings from Youth and the Olympic Movement: X Mizhnarodna konferentsiya (24-25 travnya 2017 roku) - 10th International Conference (pp. 415-416) [in Ukrainian].

11. Finni, N.R. (2005). Pebenok s cerebral'nym paralichom. Pomoshch', uhod, razvitie [Baby with cerebral palsy. Assistance, care, development]. Moscow: Terevinf, 336 [in Russian]

12. Shevcov, A.G., Hvorova, G.M. (2013). Suchasni mizhdystsyplinarni pidkhody do etapnoyi kompleksnoyi reabilitatsiyi ditey iz tserebral'nym paralichem [Modern interdisciplinary approaches to the stage complex rehabilitation of children with cerebral palsy]. Naukovyy chasopys natsional'noho pedahohichnoho universytetu imeni M.P. Drahomanova (ser. 19 «Korektsiyna pedahohika ta spetsial'na psykholohiya») - Journal of the National Pedagogical 
19. Helders P. J. Creating and being created: the changing panorama of paediatric rehabilitation / P. J. Helders, R. H. Engelbert, J. W. Custers, J. W. Gorter, T. Takken, J. van der Net // Pediatr. Rehabil. - 2003. - Vol. 6. - P. 5-12.

20. Hertsyk A. SMART goal setting in physical therapy / A. Hertsyk // Фіз. виховання, спорт і культура здоров'я у сучасному суспільстві : зб. наук. праць. - 2016. - № 2 (34). - С. 57-63.

21. King S. Family-centered service for children with cerebral palsy and their families: a review of the literature / S. King, R. Teplicky, G. King, P. Rosenbaum // Semin. Pediatr. Neurol. - 2004. - Vol. 11, Iss. 1. - P. 78-86.

22. Law M. Factors affecting family-centred service delivery for children with disabilities / M. Law, S. Hanna, G. King, P. Hurley, S. King, M. Kertoy, P. Rosenbaum // Child Care Health Dev. - 2003. - Vol. 29. Iss. 5. - P. 357-366.

23. Styer-Acevedo J. Physical therapy for the child with cerebral palsy / J. Styer-Acevedo // Pediatric physical therapy / J. S. Tecklin (ed.). - 3rd ed. Philadelphia : Lippincott Williams \& Wilkins, 1999. - P. 179-230.

24. Trabacca A. The ICF-CY perspective on the neurorehabilitation of cerebral palsy: a single case study / A. Trabacca, L. Russo, L. Losito et al. // J. Child Neurol. - 2012. - Vol. 27, Iss. 2. - P. 183-190.

25. Trabacca A. Multidisciplinary rehabilitation for patients with cerebral palsy: improving long-term care / A. Trabacca, T. Vespino, A. Di Liddo, L. Russo // J. of Multidisciplinary Healthcare. - 2016. - Vol. 9. - P. 455-462.
University named after M.P. Drahomanov (Ser. 19 «Correctional Pedagogy and Special Psychology»), 23, 281-285 [in Ukrainian].

13. Bovend'Eerdt, T.J., Botell, R.E., \& Wade, D.T. (2009). Writing SMART rehabilitation goals and achieving goal attainment scaling: a practical guide. Clin Rehab., Vol. 23, 352-361.

14. Choi, B.C., \& Pak, A.W. (2006). Multidisciplinarity, interdisciplinarity and transdisciplinarity in health research, services, education and policy: 1 Definitions, objectives, and evidence of effectiveness. Clin. Invest. Med., Vol. 29, Iss. 6, 351-364

15. Dirks, T., \& Hadders-Algra, M. (2011). The role of the family in intervention of infants at high risk of cerebral palsy: a systematic analysis. Dev. Med. Child Neurol., Vol. 53 (Suppl 4), 62-67.

16. Fahimzad, A., Babaie, D., Ghoroubi, J., Zahed, G.H., \& Rafieli, T. (2013). Common infections among disabled children admitted to hospital. Archives of Pediatric Infectious Diseases, Vol. 1, Iss. 2, 71-74. Retrieved from doi:10.5812 /pedinfect.9075.

17. Fedrizzi, E. (Ed.). (2002). GIPCI Gruppo Italiano Paralisi Cerebrali Infantili La valutazione delle funzioni adattive nel bambino con paralisi cerebrale. Milan: Franco Angeli Editore, 225.

18. Gunel, K.M. (2009). Rehabilitation of children with cerebral palsy from a physiotherapist's perspective. Acta Orthop. Traumatol. Turc., Vol. 43, Iss. 2, 173-180. Retrieved from doi:10.3944 /AOTT.2009.173.

19. Helders, P.J., Engelbert, R.H., Custers, J.W., Gorter, J.W., Takken, T. \& van der Net, J. (2003). Creating and being created: the changing panorama of paediatric rehabilitation. Pediatr. Rehabil., Vol. 6, 5-12.

20. Hertsyk, A. (2016). SMART goal setting in physical therapy. Physical education, sport and health culture in modern society, 2 (34), 57-63.

21. King, S., Teplicky, R., King, G., \& Rosenbaum, P. (2004). Family-centered service for children with cerebral palsy and their families: a review of the literature. Semin. Pediatr. Neurol., Vol. 11, Iss. 1, 78-86.

22. Law, M., Hanna, S., King, G., Hurley, P., King, S., Kertoy, M., \& Rosenbaum, P. (2003). Factors affecting family-centred service delivery for children with disabilities. Child Care Health Dev., Vol. 29, Iss. 5, 357-366.

23. Styer-Acevedo, J. (1999). Physical therapy for the child with cerebral palsy. In: Pediatric physical therapy. J.S. Tecklin (Ed.). (3rd ed.). Philadelphia: Lippincott Williams \& Wilkins, 179-230.

24. Trabacca, A., Russo, L., Losito, L., et al. (2012). The ICF-CY perspective on the neurorehabilitation of cerebral palsy: a single case study. J. Child Neurol., Vol. 27, Iss. 2, 183-190

25. Trabacca, A., Vespino, T., Di Liddo, A., \& Russo, L. (2016). Multidisciplinary rehabilitation for patients with cerebral palsy: improving long-term care. J. of Multidisciplinary Healthcare, Vol. 9, 455-462. 